\title{
Antiplatelet Therapy for Acute Respiratory Distress Syndrome
}

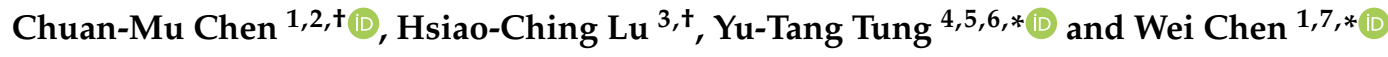 \\ 1 Department of Life Sciences, National Chung Hsing University, 145 Xingda Road, Taichung 402, Taiwan; \\ chchen1@dragon.nchu.edu.tw \\ 2 The iEGG and Animal Biotechnology Center, and the Rong Hsing Research Center for Translational \\ Medicine, National Chung Hsing University, Taichung 402, Taiwan \\ 3 Division of Respiratory Therapy, Chia-Yi Christian Hospital, Chiayi 60002, Taiwan; 00614@cych.org.tw \\ 4 Graduate Institute of Metabolism and Obesity Sciences, Taipei Medical University, Taipei 110, Taiwan \\ 5 Nutrition Research Center, Taipei Medical University Hospital, Taipei City 110, Taiwan \\ 6 Cell Physiology and Molecular Image Research Center, Wan Fang Hospital, Taipei Medical University, \\ Taipei 110, Taiwan \\ 7 Division of Pulmonary and Critical Care Medicine, Chia-Yi Christian Hospital, Chiayi 60002, Taiwan \\ * Correspondence: f91625059@tmu.edu.tw (Y.-T.T.); peteralfa2004@gmail.com (W.C.); \\ Tel.: +886-227361661 (Y.-T.T.); +886-5-2779365 (ext. 6172) (W.C.) \\ + These authors contributed equally to this work.
}

Received: 11 June 2020; Accepted: 18 July 2020; Published: 21 July 2020

check for updates

\begin{abstract}
Acute respiratory distress syndrome (ARDS) is a common and devastating syndrome that contributes to serious morbidities and mortality in critically ill patients. No known pharmacologic therapy is beneficial in the treatment of ARDS, and the only effective management is through a protective lung strategy. Platelets play a crucial role in the pathogenesis of ARDS, and antiplatelet therapy may be a potential medication for ARDS. In this review, we introduce the overall pathogenesis of ARDS, and then focus on platelet-related mechanisms underlying the development of ARDS, including platelet adhesion to the injured vessel wall, platelet-leukocyte-endothelium interactions, platelet-related lipid mediators, and neutrophil extracellular traps. We further summarize antiplatelet therapy, including aspirin, glycoprotein IIb/IIIa receptor antagonists, and P2Y12 inhibitors for ARDS in experimental and clinical studies and a meta-analysis. Novel aspirin-derived agents, aspirin-triggered lipoxin, and aspirin-triggered resolvin D1 are also described here. In this narrative review, we summarize the current knowledge of the role of platelets in the pathogenesis of ARDS, and the potential benefits of antiplatelet therapy for the prevention and treatment of ARDS.
\end{abstract}

Keywords: acute respiratory distress syndrome; antiplatelet; aspirin; therapy

\section{Introduction}

\subsection{Definition and Epidemiology of ARDS}

Acute respiratory distress syndrome (ARDS), or acute lung injury, is a devastating syndrome that contributes to serious morbidities and mortality in critically ill patients. The definition of this syndrome includes the acute onset of respiratory failure, bilateral infiltrates observed on chest radiographs, hypoxemia with a $\mathrm{PaO}_{2} / \mathrm{FiO}_{2}$ ratio $\leq 300 \mathrm{mmHg}$ with at least positive end-expiratory pressure of $5 \mathrm{cmH}_{2} \mathrm{O}$, and no evidence of left atrial hypertension [1,2]. A variety of clinical disorders are associated with the development of ARDS, including direct lung injury, such as bacterial pneumonia, aspiration of gastric contents, or indirect lung injury, such as sepsis, trauma, and transfusion of blood product [3]. The crude incidence of ARDS was around 15 to 80 per 100,000 people per year worldwide [4,5], and the 
mortality rate is high (approaching 40\%) [4]. The only effective management to date to improve the survival rate of this syndrome is a protective lung strategy, with lower tidal volume ventilation [6]. Although numerous promising therapies have been effective in the prevention of ARDS in experimental models, the successful translation to clinical application is still lacking [7-9]. In addition, in those who survive the illness, ARDS caused a substantial social burden, such as reduced exercise stamina and health-related quality of life, and increased costs and use of health care services [4,10-15]. Therefore, the discovery of medications to prevent the development of ARDS is crucial.

\subsection{Pathogenesis of ARDS}

The pathological features of ARDS are best described at three time points: acute, subacute, and chronic phases [16-18]. The acute or exudative phase (the first 1-6 days) is characterized by the influx of protein-rich edema fluid, accompanied by the accumulation of neutrophils, macrophages, exosomes [19], and red blood cells (polymorphonuclear leukocyte [PMN] predominant) into the air spaces as a consequence of the increased permeability of the alveolar-capillary barrier [20,21], as shown in Figure 1. As a result of both endothelial and epithelial injury, denuding of the alveolar epithelium and prominent hyaline membranes can be seen [3,22]. The robust inflammatory response is due to the release of oxidants, proteases, and other potentially toxic agents from activated leukocytes [23,24]. In the air space, alveolar macrophages secrete cytokines, interleukin (IL)-1, $-6,-8$, and -10 , and tumor necrosis factor- $\alpha$ (TNF- $\alpha)$, which act locally to stimulate chemotaxis and activate neutrophils. Macrophages also secrete other cytokines, including IL-1, -6, and -10. IL-1 can also stimulate the production of extracellular matrix by fibroblasts. Neutrophils can release oxidants, proteases, leukotrienes, and other pro-inflammatory molecules, such as platelet-activating factor (PAF). An imbalance between pro-inflammatory and anti-inflammatory mediators can be found in ARDS. A number of anti-inflammatory mediators are also present in the alveolar milieu, including IL-1-receptor antagonist, club cell protein 16 [25], soluble tumor necrosis factor receptor, autoantibodies against IL-8, and cytokines such as IL-10 and -11 [3]. In the subacute or proliferative phase (the next 7-14 days), some edema has usually been reabsorbed, and is often accompanied by interstitial fibrosis, a proliferation of type 2 alveolar cells, and the disruption of capillary function, due to microvascular thrombus formation. Infiltration of fibroblasts and collagen deposition may also be observed. Some experts view ARDS as a vascular microthombotic disease, and its pathogenesis is based on a novel "two-path unifying theory" of hemostasis and "two-activation theory of the endothelium", promoting molecular pathogenesis [26]. Some patients have a rapid resolution of the disorder [27], but others have progression to fibrotic lung injury, which is called the chronic or fibrotic phase (usually after 14 days). In the chronic phase, there is a resolution of the acute neutrophilic infiltrate with more mononuclear cells and alveolar macrophages in the alveoli, and often more fibrosis, with ongoing evidence of alveolar epithelial repair [17].

Overall, dysregulated inflammation [28,29], the inappropriate accumulation and activity of leukocytes and platelets [30], uncontrolled activation of coagulation pathways, and altered permeability of alveolar endothelial and epithelial barriers are pathophysiological hallmarks of ARDS [3,31,32]. Of note, endotheliopathy activates two independent molecular pathways: inflammatory and microthrombotic. The inflammatory pathway initiates inflammation, but the microthrombotic pathway more seriously produces "microthrombi strings" composed of platelet- von Willebrand factor multimer complexes, which become anchored on injured endothelial cells and causes disseminated intravascular microthrombosis [26]. Activated neutrophils affect surrounding lung tissue via several potentially pathogenic cellular mechanisms, including the release of lysosomal proteolytic enzymes [33], the production of prostanoids [34], and the generation of highly reactive oxygen radicals and intermediates [35]. All these mechanisms lead to tissue damage, increased permeability of the alveolar-capillary barrier, and the formation of protein-rich lung edema [36]. 


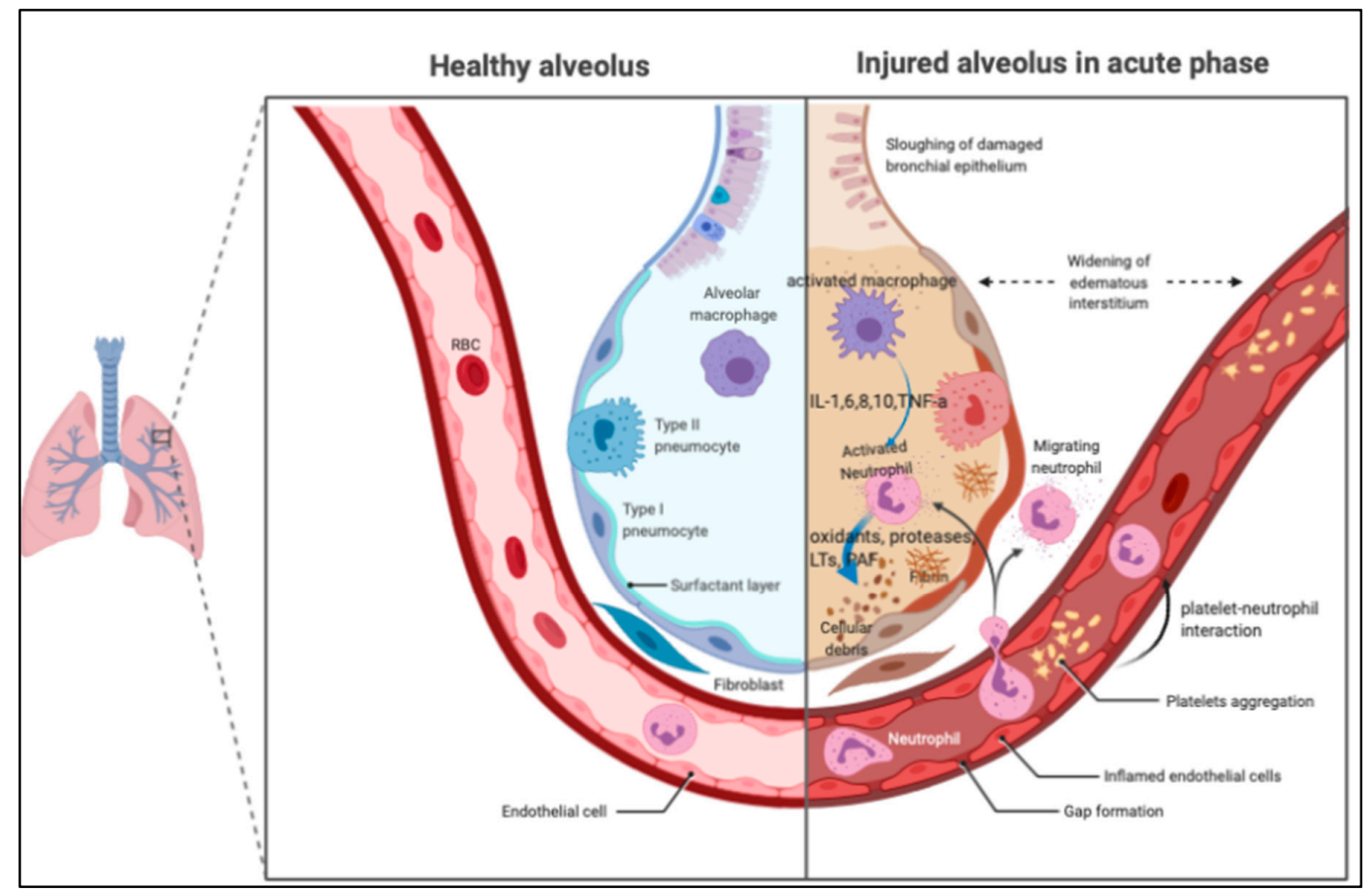

Figure 1. The pathological features of acute respiratory distress syndrome (ARDS) in the acute phase. In the air space, alveolar macrophages secrete cytokines locally to stimulate chemotaxis and activate neutrophils. Neutrophils can release oxidants, proteases, leukotrienes, and other pro-inflammatory molecules, such as platelet-activating factor (PAF). PAF: platelet-activating factor; IL: interleukin; TNF: tumor necrosis factor; LTs: leukotriene.

\section{Mechanisms of Platelet in Lung Inflammation}

\subsection{The Role of Platelet in the ARDS}

Platelets are anucleated fragments of bone marrow megakaryocytes of approximately 2-4 $\mu \mathrm{m}$ in diameter, and contain glycogen, mitochondria, and at least three types of granules (dense core granules, lysosomes, and $\alpha$-granules). Following activation, platelets can secrete the content of the granules, change their shape, and upregulate the expression of adhesion molecules including P-selectin, platelet and endothelial cell adhesion molecule 1 (PECAM-1, also known as CD31), glycoprotein (GP) $\mathrm{Ilb} / \mathrm{IIIa}(\alpha \operatorname{Ilb} \beta 3$ ) integrin, fibronectin, and thrombospondin [37]. PECAM1 is a member of the immunoglobulin superfamily of adhesion molecules localized at endothelial cell-cell junctions, and contributes to the maintenance of vascular integrity in resting cells, as well as playing a role in the restoration of vascular integrity following barrier disruption [38]. PECAM1 can be cleaved from endothelial cells by a number of mechanisms, including shear stress, resulting in a secreted, shed form of protein (sPECAM1) that is soluble, and can be released into circulation, exerting proinflammatory effects. The upregulation of PECAM1 and/or reducing sPECAM1 through extracorporeal removal or pharmacologic inhibition might be a novel therapeutic strategy in ARDS [39]. Platelets have an increasingly recognized role in the inflammatory response, leading to the development of ARDS. The possible mechanisms by which platelets contribute to ARDS include the activation of endothelial cells by the release of pro-inflammatory mediators [40-46] and adherence of platelets to lung capillary endothelial cells leading to the activation of attached leukocytes [47], as shown in Figure 2. 


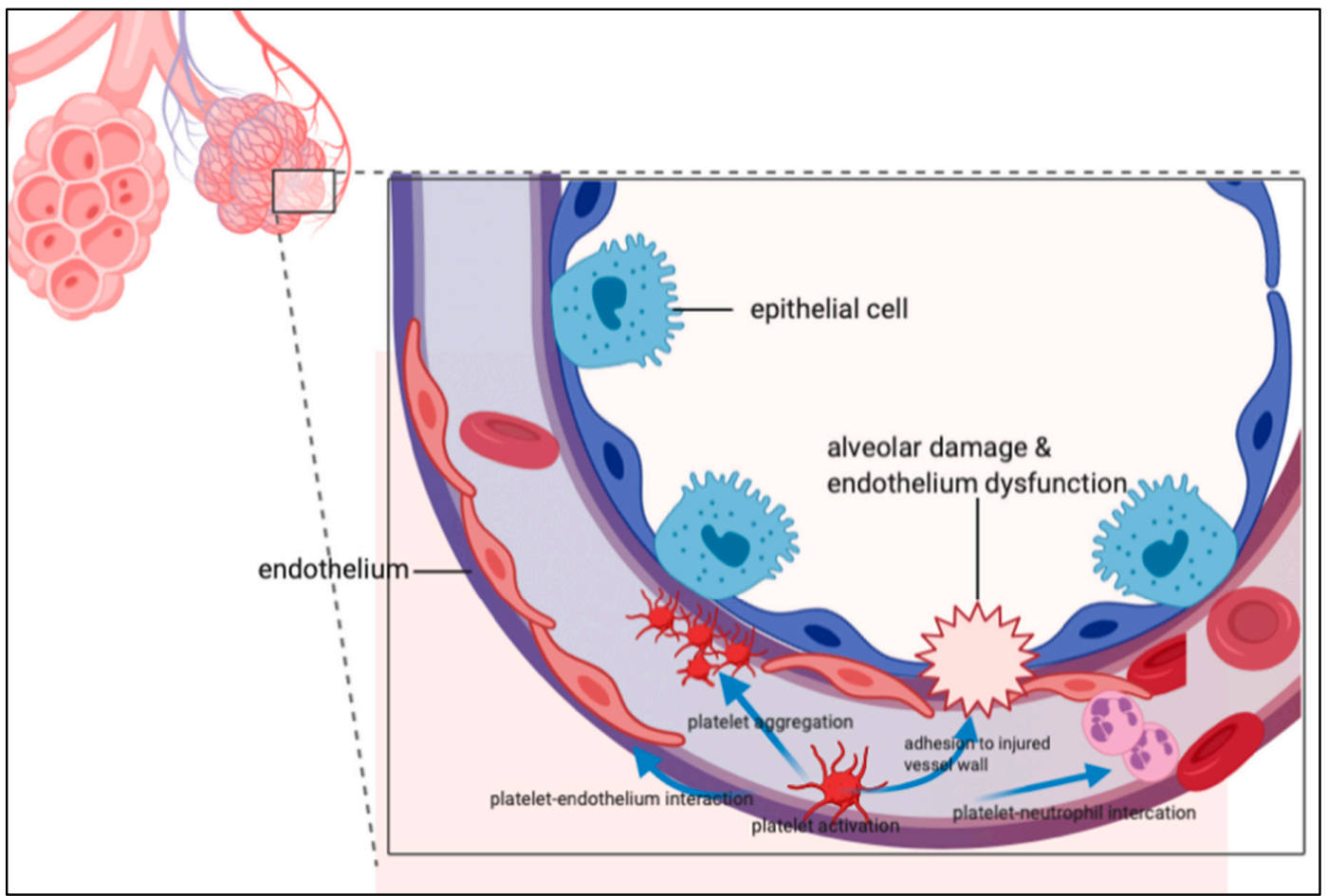

Figure 2. The role of platelets in acute respiratory distress syndrome. Platelets have an increasingly recognized role in the inflammatory response leading to the development of ARDS. The possible mechanisms by which platelets contribute to ARDS include the activation of endothelial cells by the release of pro-inflammatory mediators and adherence of platelets to lung capillary endothelial cells leading to activation of attached leukocytes.

\subsection{Platelet Adhesion to the Injured Vessel Wall}

Not only neutrophils, but also platelets, are shown to adhere to injured capillary endothelium in the acute phase of ARDS. At sites of vascular injury and endothelial denudation, platelets adhere to activated endothelial cells or in the subendothelial matrix [48] directly or indirectly. The direct binding of platelets to extracellular collagen at sites of vascular injury is mediated via several GPs. Platelet surface receptors GP Ia/IIa, GPIV, and GPVI interact directly with collagen, and platelet surface receptors GP $\mathrm{Ib} / \mathrm{V} / \mathrm{IX}$ interact with von Willebrand factor [49]. Binding the GP Ib/IX/V complex to von Willebrand factor initiates the activation of the integrin $\alpha \mathrm{IIb} \beta 3$ on platelets, resulting in platelet aggregates via RGD-containing bridging molecules, such as fibrinogen, fibronectin, and thrombospondin [50-52]. In addition, the platelet receptor C-type lectin-like 2 (CLEC-2) has been shown to regulate vascular integrity at sites of acute inflammation [53]. CLEC-2 expressed in platelets is required to limit neutrophil recruitment, which, in turn, limits lung function decline in a mouse model of ARDS. In addition, the expression of the CLEC-2 ligand podoplanin is required in hematopoietic cells to limit neutrophil chemokine expression and, consequently, arterial oxygen saturation decline [54].

\subsection{Platelet-Leukocyte-Endothelium Interactions}

Platelet-neutrophil-endothelium interactions are involved in the lung inflammation of ARDS. As shown in Figure 3, platelet adhesion to the intact endothelium is mediated by at least two different types of adhesion molecules, selectins and integrins. GP Ilb/IIIa ( $\alpha \mathrm{IIb} \beta 3$ integrin) is an important adhesion molecule in platelets that is responsible for mediating platelet aggregation and some platelet-neutrophil-interactions. Injection of platelet-specific monoclonal antibodies against the GP $\mathrm{IIb} / \mathrm{III}$ a receptor in mice causes early signs of acute lung injury with increased cellularity in the lung interstitium and rapid engorgement of alveolar septal vessels [55]. P-selectin, a type I membrane protein, is stored in the $\alpha$-granules of platelets and Weibel-Palade bodies of endothelial cells, from 
where it is rapidly expressed on the cell surface by a $\mathrm{Ca}^{2+}$-dependent translocation to the plasma membrane [56]. Upon activation, platelets bind to endothelial cells by expressing P-selectin via GP Ib $\alpha$ and P-selectin glycoprotein ligand-1 (PSGL-1). Following a conformational change, $\alpha \mathrm{Ilb} \beta 3$ integrins establish strong adhesion of platelets by binding to small bridging ligands, such as fibrinogen or vitronectin, which interact with the endothelial adhesion molecules $\alpha v \beta 3$ or intercellular adhesion molecule 1 (ICAM-1) [57]. To attract the neutrophils, P-selectin mediates the initial binding ("capturing") of platelets to leukocytes and leukocytes to endothelial cells. Following the adhesion of neutrophils to platelets, neutrophils are activated through PSGL-1 [58], the triggering receptor expressed on myeloid cells (TREM)-1 [59], lipid mediators, and chemokines presented by platelets. In an experimental study, Zhao et al. showed that the blockade of PSGL-1 results in diminished alveolar neutrophil transmigration in lipopolysaccharide (LPS)-induced acute lung injury in mice, indicating that platelets and their interaction with neutrophils are requisite for the development of LPS-induced lung inflammation and injury [60]. TREM-like transcript-1 (TLT-1) is a type-1 immunoglobulin domain receptor that is stored in platelet $\alpha$-granules and, upon platelet activation, translocate to the surface. TLT- 1 uses fibrinogen to govern the transition between inflammation and hemostasis, and facilitates controlled leukocyte transmigration during the progression of ARDS [61]. Collectively, activated platelets play a crucial role in host defense, influencing pulmonary neutrophil recruitment, and contribute to the development of ARDS [40,62,63]. Upon activation, platelets can adhere to other platelets or leukocytes, forming neutrophil platelet aggregates (NPAs) or monocyte-platelet aggregates (MPAs), and to exposed endothelium at sites of inflammation [64]. The presence of circulating leukocyte platelet aggregates (LPAs) is a sensitive indicator of platelet activation, and thrombus formation has been associated with the severity of acute lung injury [65]. Furthermore, Ortiz-Muñoz et al. reported that the dynamic formation of LPAs observed by using lung intravital microscopy sharply increased with acute lung injury [66]. The measurement of LPA in patients with ARDS and other critical illnesses could be a useful biomarker of inflammation, and could be measured serially, to assess therapeutic responses to treatment with pro-resolving lipid mediators.

Quiescent state $\quad$ Active state

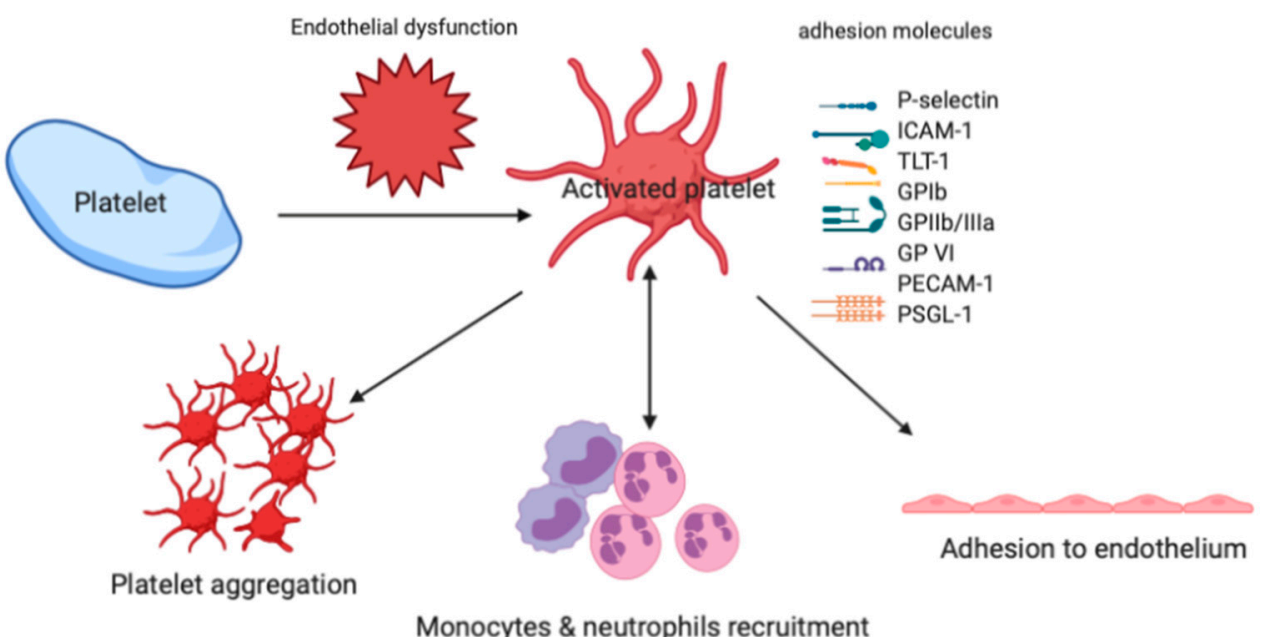

Figure 3. The role of specific adhesion molecules in the platelet-neutrophil interaction, adhesion to endothelium, and platelet aggregation. Triggering receptor expressed on myeloid cells (TREM)-like transcript-1: TLT-1; intercellular adhesion molecule-1: ICAM-1; P-selectin glycoprotein ligand 1: PSGL-1; glycoprotein: GP; Platelet and endothelial cell adhesion molecule-1: PECAM-1.

\subsection{Lipid Mediators and Platelet Aggregation}

The aggregation of platelets at sites of lung injury to facilitate the recruitment of neutrophils to the injured alveolus is an important mechanism in the development of ARDS [40]. Lipid mediators 
play a pivotal role in the aggregation of platelets and regulation of inflammation, and arachidonic acid-derived products, such as thromboxane (TX) and leukotrienes (LTs), have been implicated as pro-inflammatory mediators of ARDS [67]. For aggregation, platelets release arachidonic acid through a membrane-bound lipase. Arachidonic acid is converted to TXA2 via a multistep process, which is a powerful mediator of platelet aggregating response. Cyclooxygenase is the key enzyme responsible for the synthesis of prostaglandins (PGs) and TXA2 in platelets. In addition, cyclooxygenase is involved in oxidative stress-induced acute lung injury, suggesting a link between neutrophil-derived oxidative stress and endothelial eicosanoid metabolism [68]. Aspirin has significant antiplatelet properties through the inhibition of cyclooxygenase enzymes that prevent TXA2 production, therefore suppressing platelet aggregation in animal models of acute lung injury [69].

Cytosolic phospholipase A2 (cPLA2) is a key enzyme for the production of inflammatory mediators, such as TXs and LTs, which are generated from arachidonic acid by cyclooxygenase and 5-lipoxygenase, respectively. Nagase et al. reported that the disruption of the gene encoding cPLA2 significantly reduced pulmonary edema, PMN sequestration, and deterioration of the gas exchange in a murine model of LPS-induced acute lung injury [70], indicating that the inhibition of CPLA2-initiated pathways may provide a therapeutic approach to acute lung injury. On the contrary, cPLA2 could act with the reactive oxygen species produced during intestinal ischemia-reperfusion, resulting in the exacerbation of the inflammatory reaction in ARDS [71]. Platelet-activating factor (PAF), a potent phospholipid activator and one of the lipid mediators of platelet aggregation, is also associated with the development of ARDS [72]. The presence of G994T polymorphism in exon 9 of the plasma PAF acetylhydrolase gene has a better survival rate in ARDS [73].

\subsection{Neutrophil Extracellular Traps (NETs)}

Sepsis syndrome is the primary etiology of ARDS and is associated with a 35-45\% incidence of ARDS development [74]. It has been hypothesized that endotoxemia and phagocytosis of bacteria are involved in the pathogenesis of septic syndrome-associated ARDS [75]. Platelets express toll-like receptors (TLRs), including TLR2 and TLR4, that recognize the common bacterial molecules peptidoglycan and LPS, respectively [76]. Activated platelets, particularly in the context of LPS stimulation, trigger the release of extracellular DNA traps (NETs), with proteolytic activity from neutrophils, serving to capture and degrade microbes [76]. These NETs are capable of trapping and killing extracellular pathogens in blood and tissues during infection [77]. However, NETs are not only produced during severe infections, but have also been observed in various inflammatory diseases [78-80]. Caudrillier et al. showed that platelet-induced NETs contribute to lung endothelial injury, and that targeting NET formation with either aspirin or a GP IIb/IIIa inhibitor decreased NET formation and lung injury in the experimental model of transfusion-related acute lung injury (TRALI) [62]. Nitrostyrene derivatives (BNSDs) have been identified as inhibitors of phospholipase and tyrosine kinase, antibacterial agents, and macrophage immune response regulators, and attenuate LPS-mediated acute lung injury via the inhibition of neutrophil-platelet interactions and NET release [81].

\section{Antiplatelet Agents in Experimental Studies}

\subsection{Aspirin}

Aspirin is a well-known, irreversible, noncompetitive inhibitor of arachidonic acid cyclooxygenase metabolism and is commonly used in clinical practice. Preclinical studies have shown that aspirin can prevent or treat ARDS by decreasing neutrophil activation and recruitment to the lung, TNF- $\alpha$ expression in pulmonary intravascular macrophages, plasma TX B2 levels, and platelet sequestration in the lungs $[62,69,82-85]$. Aspirin also reduces the severity of edema and vascular permeability in oxidative stress-induced acute lung injury [68]. Looney et al. showed that treatment with aspirin prevented lung injury and mortality, but blocking P-selectin or CD11b/CD18 pathways did not. 
These data suggest a 2-step mechanism of TRALI: priming hematopoietic cells, followed by vascular deposition of activated neutrophils and platelets that then mediate severe lung injury [69]. In addition, Bates et al. showed that delayed postoperative neutrophil apoptosis is significantly preserved in patients taking $300 \mathrm{mg}$ of aspirin on the day before surgery, indicating that aspirin may be able to ameliorate to promote a resolution for persistent inflammation [86].

Another function of aspirin in treating acute lung injury is the acetylation of cyclooxygenase-2 (COX-2) that causes a conformational change, leading to the inhibition of prostanoid synthesis [87]. The acetylation of COX-2 switches catalytic activity to convert arachidonic acid to 15R-hydroxyeicosatetraenoic acid, which can be subsequently converted to 15(R)-epi-lipoxin A4 (15[R]-epi-LXA4), also known as aspirin-triggered lipoxin (ATL) [88]. Lipoxins are endogenous lipid mediators generated during inflammation that can block inflammatory cell recruitment, inhibit cytokine release, and decrease vascular permeability, which collectively are anti-inflammatory properties [89,90]. Ortiz-Muñoz et al. showed that aspirin treatment increased levels of ATL, and treatment with ATL in both lipopolysaccharide and TRALI models protected the lung from acute lung injury [66]. In addition, delayed neutrophil apoptosis is a prominent feature of ARDS [91], which results in prolonging the period of lung injury and hypoxia. Aspirin has previously been shown to preserve neutrophil apoptosis [86], and experimental evidence suggests that ATL restores neutrophil apoptosis and enhances the resolution of alveolar inflammation [92].

Neutrophil recruitment to sites of lung injury may also be modulated through aspirin-triggered anti-inflammatory mediators. In the case of aspirin treatment, aspirin-acetylated COX-2 generates 17R-HDHA, which, following sequential oxygenation by 5-lipoxygenase, results in the production of 17-epi-RvD1, also known as aspirin-triggered RvD1 (AT-RvD1). AT-RvD1 is the 17R epimer of RvD1 (7S, 8R, 17R-trihydroxy-4Z, 9E, 11E, 13Z,15E, 19Z-docosahexaenoic acid), which is more resistant to catalysis than RvD1 [93]. Eickmeier et al. showed that AT-RvD1 inhibited neutrophil-platelet heterotypic interactions by downregulating both P-selectin and its ligand CD24. AT-RvD1 also significantly decreased levels of bronchoalveolar lavage fluid pro-inflammatory cytokines, including IL-1 $\beta$, IL-6, and TNF- $\alpha$, and decreased nuclear factor- $\mathrm{kB}$ (NF- $\mathrm{kB}$ )-phosphorylated p65 nuclear translocation in an acid-initiated lung injury model. This suggests that aspirin therapy might decrease the severity and augment the resolution of ARDS [85]. Tang et al. demonstrated, for the first time, that AT-RvD1- and p-RvD1-treated mice have significantly reduced lung inflammatory responses, including TNF- $\alpha$, IL-6, keratinocyte cell-derived chemokine, and macrophage inflammatory protein (MIP)-1 $\alpha$ and reduced lung injury after immunoglobulin G immune complex deposition, suggesting a new approach to blocking immune complex-induced inflammation [94]. Our study also showed that pretreatment with aspirin reduced NF- $\kappa B$ activation, active oxygen species expression, the number of macrophages, neutrophil infiltration, and lung edema compared with hyperoxia-only treatment in NF- $\mathrm{B}$-luciferase transgenic mice [95]. Cox et al. showed that AT-RvD1 treatment resulted in reduced oxidative stress, increased glutathione production, and significantly decreased tissue inflammation, indicating that AT-RvD1 is an effective therapy for prolonged hyperoxic exposure in this murine model [96]. A brief summary of the aspirin effect is shown in Figure 4.

\subsection{GP IIb/IIIa Antagonists}

GP IIb/IIIa receptor inhibitors that mediate platelet-platelet binding through fibrinogen [97] are currently used as a preventive medication for coronary artery disease after percutaneous coronary intervention. Commercially available GP IIb/IIIa receptor inhibitors include abciximab, eptifibatide, and tirofiban.

In a murine model of influenza A virus infections, GP IIb/IIIa antagonist, eptifibatide is shown to protect mice from death caused by influenza viruses, by reducing aggregates of activated platelets [98]. Sharron showed that eptifibatide attenuates platelet granzyme B-mediated apoptosis and results in less severe sepsis and extended survival in a murine model of abdominal sepsis [99], indicating that the GP IIb/IIIa antagonist may be a target for the treatment of sepsis-related ARDS. Caudrillier et al. also 
showed that another GP IIb/IIIa antagonist, tirofiban, was shown to be effective in the treatment of TRALI by decreasing soluble NET components [62].

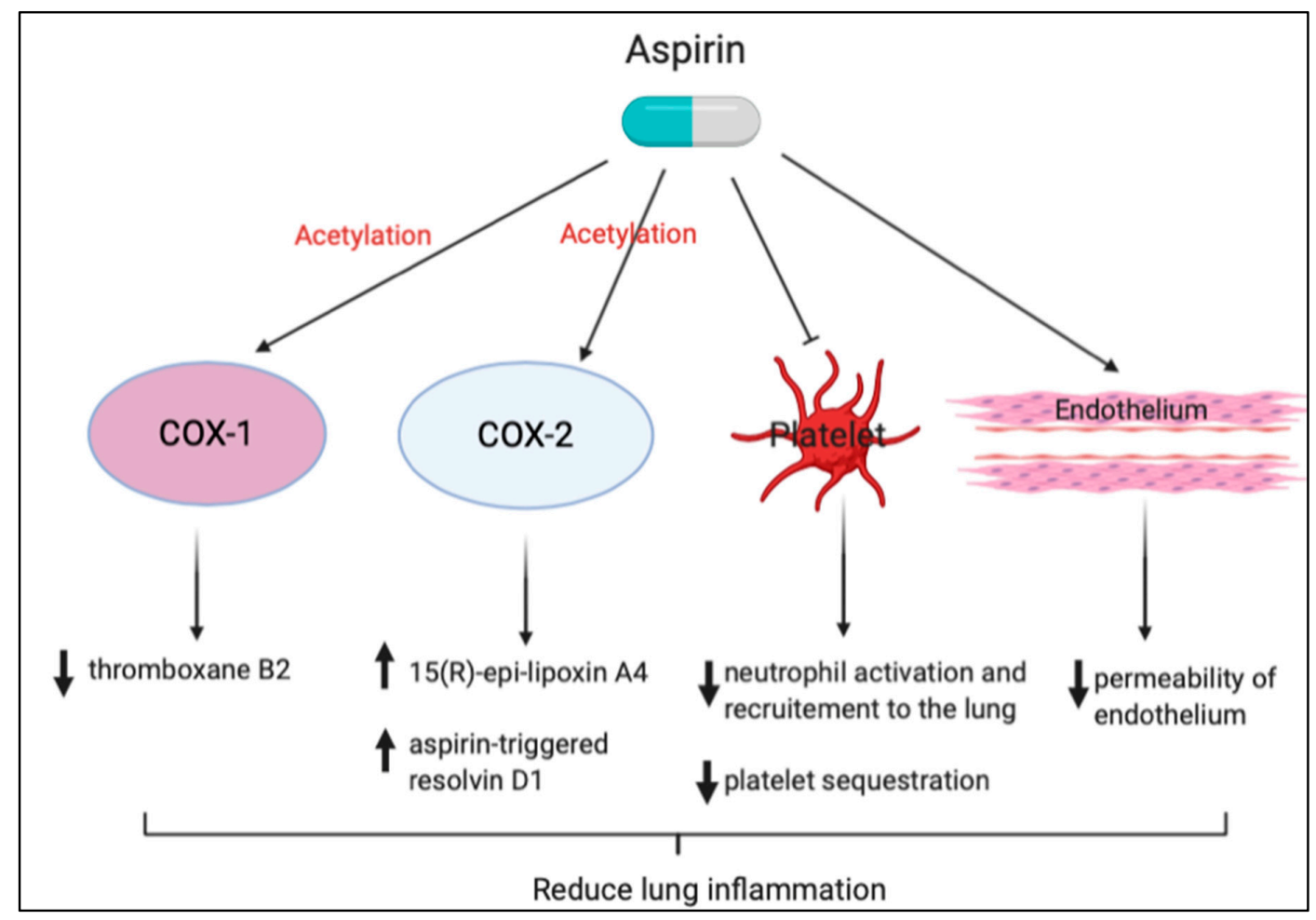

Figure 4. Protective effects of aspirin against lung inflammation. Neutrophil recruitment to the sites of lung injury may also be modulated through aspirin-triggered anti-inflammatory mediators.

\subsection{P2Y12 Inhibitors}

The P2Y12 protein, a chemoreceptor for adenosine diphosphate, is found mainly but not exclusively on the surface of platelets and belongs to the Gi class of a group of $\mathrm{G}$ protein-coupled purinergic receptors [100]. Commercially available P2Y12 inhibitors include clopidogrel, prasugrel, and ticagrelor, mainly indicated for cardiovascular diseases. Several studies have shown that clopidogrel not only diminishes the risk of atherothrombotic events, but also reduces the markers of systemic inflammation, including C-reactive protein, soluble CD62P (P-selectin) and CD54, pro-inflammatory cytokines, and platelet-leukocyte conjugates [101]. Harr et al. showed that rats pretreated with clopidogrel were protected from trauma/hemorrhagic shock-related acute lung injury by reducing platelet activation and aggregation, microthrombi formation, and leukocyte recruitment [102]. Le et al. also showed that clopidogrel had a similar effect as the GP IIb/IIIa antagonist, to protect mice from death caused in an experimental model of influenza virus A infection [98]. Tuinman et al. reported that clopidogrel attenuates LPS-induced lung injury in mice, but its effect is inferior to high-dose aspirin [83].

For antiplatelet therapy to treat or prevent ARDS, there are several major differences between animal experiments and human studies. First, the lung injury model of animal experiments cannot fully comply with the process of human acute lung injury. Second, people who develop lung injury usually have comorbidities, which can lead to different outcomes even with the same treatment. Third, the therapeutic dose for animals, once used in humans, may be too high and cause side effects. Fourth, there are too many causes for ARDS in the human body, which results in so-called heterogeneity. For these reasons, it is quite difficult for a single drug to be successful in people with ARDS. 


\section{Antiplatelet Agents in Clinical Studies}

The human study regarding aspirin for treating or preventing ARDS was conducted around 20 years ago. As shown in Table 1, Erlich and colleagues performed a retrospective analysis of 161 patients from Olmsted County, Minnesota, to assess a potential association between prehospital use of antiplatelet agents and the development of ARDS in at-risk patients. Antiplatelet agents included aspirin, clopidogrel, and ticlopidine in their study. They showed that antiplatelet therapy was associated with a reduced incidence of ARDS (12.7\% vs $28.0 \%$; OR, $0.37 ; 95 \%$ CI, $0.16-0.84 ; p=0.02)$, even after adjusting for confounding variables [103]. Meanwhile, $\mathrm{O}^{\prime} \mathrm{Neal}$ et al., from our laboratory, conducted a secondary analysis of a prospective study with 575 patients in the validating acute lung injury markers for diagnosis (VALID) cohort, and showed that concurrent statin and aspirin use, but not aspirin alone, was associated with the reduced risk of ARDS [104]. However, this study was likely underpowered to show an independent association between prehospital aspirin use and the reduced risk of ARDS, given the large proportion of patients who were receiving both prehospital statin and prehospital aspirin therapy. Later, Kor et al., from a group of lung injury prevention study investigators (USCIITG-LIPS), performed a multicenter prospective observational study to evaluate the association between prehospitalization aspirin therapy and incident acute lung injury in a heterogeneous cohort of at-risk medical patients. In total, 3855 at-risk patients were enrolled from 22 hospitals over a 6-month period in the United States and Turkey. Nine hundred seventy-six $(25.3 \%)$ were receiving aspirin at the time of hospitalization. Two hundred forty (6.2\%) patients developed acute lung injury. After adjusting for the propensity to receive aspirin therapy, they found that no statistically significant associations between prehospitalization aspirin therapy and ARDS [105]. However, the overall incidence of ARDS in their study was low $(6.2 \%)$. To further characterize the possible benefit of prehospital aspirin use in ARDS, we performed a new cross-sectional analysis of the entire prospectively collected VALID cohort, with approximately 1149 critically ill patients (age $\geq 40$ ) enrolled during a 6-year interval. Our data showed that patients with prehospital aspirin had a significantly lower incidence of ARDS $(27 \%$ vs. $34 \%, \mathrm{p}=0.034)$. In a multivariable, propensity-adjusted analysis, including age, gender, race, sepsis, and APACHE II, prehospital aspirin use was associated with a decreased risk of ARDS (OR 0.66, 95\% CI 0.46-0.94) in the entire cohort, and a subgroup of 725 patients with sepsis (OR $0.60,95 \%$ CI 0.41-0.90) [106]. In a prospective study of 202 patients with ARDS, aspirin therapy, given either before or during the hospital stay, was associated with a reduction in ICU mortality (OR: 0.38, CI: 0.15-0.96, $\mathrm{p}=0.04$ ) by using multivariate logistic regression analysis [107].

A group of the lung injury prevention study with aspirin (LIPS-A) conducted a multicenter, double-blind, randomized clinical trial, testing whether early administration of aspirin would result in a reduced incidence of ARDS in adult patients at high risk. Approximately 400 participants from 14 hospitals across the United States were enrolled [108]. The results showed that, among at-risk patients presenting to the emergency department, the use of aspirin compared with placebo did not reduce the risk of ARDS at 7 days [109]. However, there were several limitations in this study, including an unexpectedly lower rate of ARDS, a large number of patients who used antiplatelets had been excluded, the time from randomization to first drug administration was longer than anticipated at study onset, and the aspirin dose chosen for this study was too low [109]. Furthermore, most studies did not have a subgroup analysis. ARDS is caused by a variety of etiologies, and we do not know whether aspirin is only beneficial for certain causes. Toner et al. suggested that aspirin can modulate multiple pathogenic mechanisms implicated in the development of sepsis-related ARDS [110]. A bold study that recruited healthy volunteers to receive either 75 or $1200 \mathrm{mg}$ aspirin for 7 days prior to LPS inhalation showed that aspirin reduced pulmonary neutrophilia and tissue-damaging neutrophil proteases (matrix metalloproteinase (MMP)-8/-9), reduced bronchoalveolar lavage concentrations of TNF- $\alpha$, and reduced systemic and pulmonary TXB2 [45]. 
Table 1. A summary of recent cohort studies into antiplatelet therapy for ARDS.

\begin{tabular}{|c|c|c|c|c|c|c|c|c|c|}
\hline Authors & Study Country & Study Design & $\begin{array}{l}\text { Patient's Inclusion } \\
\text { Criteria }\end{array}$ & $\begin{array}{l}\text { Patient } \\
\text { No. }\end{array}$ & Medications & $\begin{array}{l}\text { Dosage } \\
\text { (mg) }\end{array}$ & $\begin{array}{l}\text { Medication Given } \\
\text { Time Point }\end{array}$ & Outcome Variables & Results \\
\hline Erlich el al. [103] & Minnesota, US & $\begin{array}{l}\text { Retrospective } \\
\text { cohort }\end{array}$ & $\begin{array}{l}\text { at least one major risk factor for } \\
\text { ALI \& age }>18 \text { years }\end{array}$ & 161 & $\begin{array}{l}\text { Any kind of } \\
\text { antiplatelet } \\
\text { medications }\end{array}$ & & $\begin{array}{l}\text { at the time of hospital } \\
\text { admission }\end{array}$ & $\begin{array}{l}\text { 1. development of ALI or ARDS } \\
\text { 2. ICU and hospital mortality }\end{array}$ & $\begin{array}{l}\text { Reduced incidence of ALI/ARDS } \\
\text { (OR:0.37) }\end{array}$ \\
\hline O'Neal Jr et al. [104] & Tennessee, US & 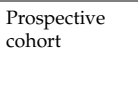 & $\begin{array}{l}\text { critically ill patients admitted to } \\
\text { the medical or surgical ICU and } \\
\text { age }>18 \text { years }\end{array}$ & 575 & $\begin{array}{l}\text { Aspirin } \\
\text { combined } \\
\text { with statin }\end{array}$ & 81or 365 daily & Prehospital use & $\begin{array}{l}\text { Development of severe sepsis, ARDS } \\
\text { Hospital mortality }\end{array}$ & $\begin{array}{l}\text { Two combined had the lowest rates of } \\
\text { severe sepsis, ALI/ARDS and } \\
\text { mortality. }\end{array}$ \\
\hline Kor et al. [105] & $\begin{array}{l}20 \text { hospitals in US \& } 2 \\
\text { in Turkey }\end{array}$ & $\begin{array}{l}\text { Prospective } \\
\text { cohort }\end{array}$ & $\begin{array}{l}\text { non-surgical patients admitted to } \\
\text { the hospital with at least one } \\
\text { major risk factor for ALI and age } \\
>18 \text { years }\end{array}$ & 3855 & Aspirin & No mention & $\begin{array}{l}\text { at the time of hospital } \\
\text { admission }\end{array}$ & $\begin{array}{l}\text { 1. development of ALI or ARDS } \\
\text { 2. ICU and hospital mortality }\end{array}$ & No significant effect \\
\hline Chen et al. [106] & Tennessee, US & $\begin{array}{l}\text { Prospective } \\
\text { cohort }\end{array}$ & $\begin{array}{l}\text { critically ill patients (age } \geq 40 \text { ) } \\
\text { admitted to the medical or } \\
\text { surgical ICU }\end{array}$ & 1149 & Aspirin & 81 or 365 daily & Prehospital use & $\begin{array}{ll}\text { 1. } & \text { Development of ARDS } \\
\text { 2. } & \text { Development of sepsis related ARDS }\end{array}$ & $\begin{array}{l}\text { Decreased risk of ARDS (OR: } 0.66 \text { ) in } \\
\text { the entire cohort also sepsis (OR: } 0.60)\end{array}$ \\
\hline Boyle et al. [107] & United Kingdom & $\begin{array}{l}\text { Prospective } \\
\text { cohort }\end{array}$ & $\begin{array}{l}\text { patients (>16 years-old) } \\
\text { requiring invasive mechanical } \\
\text { ventilation admitted to the } \\
\text { medical or surgical ICU }\end{array}$ & 202 & Aspirin & No mention & $\begin{array}{l}\text { both pre-admission } \\
\text { and during ICU stay }\end{array}$ & ICU mortality & Reduction in ICU mortality (OR: 0.38) \\
\hline Kor et al. [109] & $\begin{array}{l}16 \text { US academic } \\
\text { hospitals }\end{array}$ & $\begin{array}{l}\text { multicenter, } \\
\text { double-blind, } \\
\text { RCT }\end{array}$ & $\begin{array}{l}\text { patients at risk for ARDS (Lung } \\
\text { Injury Prediction Score } \geq 4 \text { ) }\end{array}$ & 7673 & Aspirin & $\begin{array}{l}325 \text { loading dose } \\
\text { followed by } 81\end{array}$ & $\begin{array}{l}\text { within } 24 \text { hours of } \\
\text { emergency } \\
\text { department } \\
\text { presentation }\end{array}$ & $\begin{array}{l}\text { 1. Development of ARDS by study day } 7 \\
\text { 2. Hospital length of stay } \\
\text { 3. }\end{array}$ & No significant effect \\
\hline Hamid et al. [45] & United Kingdom & $\begin{array}{l}\text { double-blind, } \\
\text { RCT }\end{array}$ & Healthy volunteers & 33 & Aspirin & 75 or 1200 for 7 days & $\begin{array}{l}\text { seven days prior to } \\
\text { LPS inhalation }\end{array}$ & Inflammatory biomarkers & $\begin{array}{l}\text { Reduced pulmonary neutrophilia and } \\
\text { tissue damaging, reduced BAL } \\
\text { concentrations of TNF- } \alpha \text { and } \\
\text { pulmonary TXB2. }\end{array}$ \\
\hline
\end{tabular}

US: United States; RCT: randomized controlled trial; ALI: acute lung injury; ARDS: acute respiratory distress syndrome; BAL: bronchoalveolar lavage; TNF: tumor necrosis factor; TX: thromboxane; OR: odds ratio. 


\section{Meta-Analysis of Clinical Studies}

As shown in Table 2, Panka et al. selected 15 pre-clinical studies and eight clinical studies, and showed that aspirin plays a beneficial role in ARDS prevention and treatment [44]. Yu et al. reviewed six studies and showed aspirin could reduce the rate of ARDS/ALI (OR:0.71) but not the mortality [111]. Jin et al. reviewed seven studies and showed significantly lower odds of ARDS in the prehospital antiplatelet therapy group, compared with subjects with no prehospital antiplatelet therapy (odds ratio: 0.68) [112]. Mohananey et al. included 17 studies, and found that there was a significant reduction in all-cause mortality in patients on antiplatelet therapy, compared to the control (OR: 0.83). Both the incidence of ARDS (OR: 0.67) and the need for mechanical ventilation (OR: 0.74) were lower in the antiplatelet group [113]. On the contrary, Wang et al. analyzed nine eligible studies, and found that antiplatelet therapy did not significantly decrease hospital mortality in high-risk patients, and an association with the incidence of ARDS remains unclear [43].

In summary, it is still unknown whether aspirin can be used to effectively prevent or treat ARDS. This can be attributed to several factors. First, there is considerable heterogeneity in ARDS itself. Several recent research directions are exploring whether different treatments can be given according to different phenotypes of ARDS [114,115]. Therefore, future research should be based on ARDS patients whose phenotype pathology is more aligned with the mechanisms of aspirin. Second, for previous studies, the starting point of aspirin administration, the dose administered, and the duration of administration are all very different. This is also one of the reasons for the inconsistency of the research results. Therefore, whether future research can detect some biomarkers to track their drug response is quite important. Third, even if the above two reasons are resolved, the mechanism of aspirin's action is only a part of the treatment or prevention of ARDS. Perhaps a cocktail therapy, which can combine aspirin with certain medications, would be beneficial for the prevention or treatment of ARDS.

Table 2. Summary of meta-analysis of the effect of aspirin on ARDS.

\begin{tabular}{|c|c|c|c|c|c|c|c|}
\hline Authors & $\begin{array}{l}\text { Enrolled Types } \\
\text { of Studies }\end{array}$ & $\begin{array}{l}\text { Enrolled Study } \\
\text { Numbers }\end{array}$ & Medications & Outcome Variables & Results & $\begin{array}{l}\text { Between-Study } \\
\text { Heterogeneity }\end{array}$ & Conclusions \\
\hline $\begin{array}{l}\text { Panka et al. } \\
\text { [44] }\end{array}$ & $1 \mathrm{RCT}, 7 \mathrm{OS}$ & 8 & Aspirin & the risk of ARDS & pooled OR was 0.59 & $\mathrm{Q}=2.44, \mathrm{I}^{2}=68 \%$ & $\begin{array}{l}\text { A beneficial role for Aspirin } \\
\text { in ARDS prevention and } \\
\text { treatment. }\end{array}$ \\
\hline $\begin{array}{l}\text { Yu et al. } \\
\text { [111] }\end{array}$ & $1 \mathrm{RCT}, 5 \mathrm{OS}$ & 6 & Aspirin & $\begin{array}{l}\text { 1. the risk of } \\
\text { ARDS/ALI } \\
\text { 2. mortality. }\end{array}$ & pooled OR was 0.71 & $\mathrm{I}^{2}=0 \%, \mathrm{P}=0.419$ & $\begin{array}{l}\text { Aspirin could provide } \\
\text { protective effect on the rate } \\
\text { of ARDS/ALI, but it could } \\
\text { not reduce the mortality. }\end{array}$ \\
\hline $\begin{array}{l}\text { Jin et al. } \\
\text { [112] }\end{array}$ & $7 \mathrm{OS}$ & 7 & $\begin{array}{l}\text { Antiplatelet agents } \\
\text { (aspirin } 75 \text { to } 300 \mathrm{mg} \\
\text { daily), (clopidogrel, } \\
75 \mathrm{mg} \text { daily), and } \\
\text { ticlo- pidine. }\end{array}$ & $\begin{array}{l}\text { 1. the risk of } \\
\text { ARDS/ALI } \\
\text { 2. mortality. }\end{array}$ & pooled OR was 0.68 & $\mathrm{I}^{2}=34 \%$ & $\begin{array}{l}\text { Pre-hospital antiplatelet } \\
\text { therapy was associated } \\
\text { with a reduced rate of } \\
\text { ARDS but had no effect on } \\
\text { the mortality in the subjects } \\
\text { at high risk }\end{array}$ \\
\hline $\begin{array}{l}\text { Mohanney } \\
\text { et al. [113] }\end{array}$ & $17 \mathrm{OS}$ & 17 & $\begin{array}{l}\text { Aspirin and other } \\
\text { antiplatelet agents }\end{array}$ & $\begin{array}{l}\text { 1. the risk of } \\
\text { ARDS/ALI } \\
\text { 2. mortality. }\end{array}$ & pooled OR was 0.67 & $\mathrm{I}^{2}=25 \%$ & $\begin{array}{l}\text { Antiplatelet therapy had an } \\
\text { improved survival, } \\
\text { decreased incidence of } \\
\text { ARDS }\end{array}$ \\
\hline $\begin{array}{l}\text { Wang et al. } \\
\text { [43] }\end{array}$ & $2 \mathrm{RCT}, 7 \mathrm{OS}$ & 9 & $\begin{array}{l}\text { Aspirin and other } \\
\text { antiplatelet agents }\end{array}$ & $\begin{array}{ll}\text { 1. } & \text { the risk of } \\
\text { ARDS/ALI } \\
\text { 2. mortality. }\end{array}$ & $\begin{array}{l}\text { pool OR was } 0.68 \\
\text { from OS; but no } \\
\text { significant } \\
\text { difference in RCT }\end{array}$ & $\begin{array}{l}I^{2}=0.0 \%, p=0.329 \\
\text { for RCT } \\
I^{2}=68.4 \%, p=0.004 \\
\text { for OS }\end{array}$ & $\begin{array}{l}\text { Whether antiplatelet } \\
\text { therapy is associated with a } \\
\text { decreased incidence of } \\
\text { ARDS in patients a a high } \\
\text { risk of developing the } \\
\text { condition remains unclear. }\end{array}$ \\
\hline
\end{tabular}

\section{Conclusions}

In summary, platelets play a crucial role in the pathogenesis of ARDS in a number of experimental studies, and antiplatelet therapy exerts a potential therapeutic benefit for ARDS in clinical studies. The main effects of antiplatelet therapy to reduce the severity of ARDS are possibly based on four directions: (1) reducing platelet adhesion to the injured vessel wall; (2) inhibiting platelet-leukocyte-endothelium interactions; (3) modulating lipid mediator related platelet aggregation, and (4) inhibiting NETs formation. Several observational studies have shown that aspirin is protective against the development of ARDS, and a large multicenter, double-blinded, randomized study showed 
no beneficial effect of aspirin on the development of ARDS. Future research should be based on ARDS patients whose phenotype pathology is more aligned with the mechanisms of antiplatelet therapy, and specific biomarkers should be developed to track their drug response.

Funding: This research work was funded by the Ministry of Science and Technology, Taiwan and Chiayi Christian Hospital, Chiayi, Taiwan, grant number 104-2314-B-705-005.

Conflicts of Interest: The authors declare no conflict of interest.

\section{References}

1. Force, A.D.T.; Ranieri, V.M.; Rubenfeld, G.D.; Thompson, B.T.; Ferguson, N.D.; Caldwell, E.; Fan, E.; Camporota, L.; Slutsky, A.S. Acute respiratory distress syndrome: The Berlin Definition. JAMA 2012, 307, 2526-2533.

2. Bernard, G.R.; Artigas, A.; Brigham, K.L.; Carlet, J.; Falke, K.; Hudson, L.; Lamy, M.; Legall, J.R.; Morris, A.; Spragg, R. The American-European Consensus Conference on ARDS. Definitions, mechanisms, relevant outcomes, and clinical trial coordination. Am. J. Respir. Crit. Care Med. 1994, 149, 818-824. [CrossRef] [PubMed]

3. Ware, L.B.; Matthay, M.A. The acute respiratory distress syndrome. N. Engl. J. Med. 2000, 342, 1334-1349. [CrossRef] [PubMed]

4. Rubenfeld, G.D.; Caldwell, E.; Peabody, E.; Weaver, J.; Martin, D.P.; Neff, M.; Stern, E.J.; Hudson, L.D. Incidence and outcomes of acute lung injury. N. Engl. J. Med. 2005, 353, 1685-1693. [CrossRef]

5. Chen, W.; Chen, Y.Y.; Tsai, C.F.; Chen, S.C.; Lin, M.S.; Ware, L.B.; Chen, C.M. Incidence and Outcomes of Acute Respiratory Distress Syndrome: A Nationwide Registry-Based Study in Taiwan, 1997 to 2011. Medicine 2015, 94, e1849. [CrossRef]

6. Acute Respiratory Distress Syndrome Network. Ventilation with lower tidal volumes as compared with traditional tidal volumes for acute lung injury and the acute respiratory distress syndrome. The Acute Respiratory Distress Syndrome Network. N. Engl. J. Med. 2000, 342, 1301-1308. [CrossRef]

7. Jepsen, S.; Herlevsen, P.; Knudsen, P.; Bud, M.I.; Klausen, N.O. Antioxidant treatment with N-acetylcysteine during adult respiratory distress syndrome: A prospective, randomized, placebo-controlled study. Crit. Care Med. 1992, 20, 918-923. [CrossRef] [PubMed]

8. Ketoconazole for early treatment of acute lung injury and acute respiratory distress syndrome: A randomized controlled trial. The ARDS Network. JAMA 2000, 283, 1995-2002.

9. Meade, M.O.; Jacka, M.J.; Cook, D.J.; Dodek, P.; Griffith, L.; Guyatt, G.H.; Canadian Critical Care Trials, G. Survey of interventions for the prevention and treatment of acute respiratory distress syndrome. Crit. Care Med. 2004, 32, 946-954. [CrossRef]

10. Avecillas, J.F.; Freire, A.X.; Arroliga, A.C. Clinical epidemiology of acute lung injury and acute respiratory distress syndrome: Incidence, diagnosis, and outcomes. Clin. Chest Med. 2006, 27, 549-557. [CrossRef]

11. Caser, E.B.; Zandonade, E.; Pereira, E.; Gama, A.M.; Barbas, C.S. Impact of distinct definitions of acute lung injury on its incidence and outcomes in Brazilian ICUs: Prospective evaluation of 7,133 patients*. Crit. Care Med. 2014, 42, 574-582. [CrossRef]

12. Herridge, M.S.; Cheung, A.M.; Tansey, C.M.; Matte-Martyn, A.; Diaz-Granados, N.; Al-Saidi, F.; Cooper, A.B.; Guest, C.B.; Mazer, C.D.; Mehta, S.; et al. One-year outcomes in survivors of the acute respiratory distress syndrome. N. Engl. J. Med. 2003, 348, 683-693. [CrossRef]

13. Herridge, M.S.; Tansey, C.M.; Matte, A.; Tomlinson, G.; Diaz-Granados, N.; Cooper, A.; Guest, C.B.; Mazer, C.D.; Mehta, S.; Stewart, T.E.; et al. Functional disability 5 years after acute respiratory distress syndrome. N. Engl. J. Med. 2011, 364, 1293-1304. [CrossRef]

14. Sasannejad, C.; Ely, E.W.; Lahiri, S. Long-term cognitive impairment after acute respiratory distress syndrome: A review of clinical impact and pathophysiological mechanisms. Crit Care 2019, 23, 352. [CrossRef]

15. Bein, T.; Weber-Carstens, S.; Apfelbacher, C.; Brandstetter, S.; Blecha, S.; Dodoo-Schittko, F.; Brandl, M.; Quintel, M.; Kluge, S.; Putensen, C.; et al. The quality of acute intensive care and the incidence of critical events have an impact on health-related quality of life in survivors of the acute respiratory distress syndrome-A nationwide prospective multicenter observational study. Ger. Med. Sci. 2020, 18, Doc01. [PubMed] 
16. Bachofen, M.; Weibel, E.R. Alterations of the gas exchange apparatus in adult respiratory insufficiency associated with septicemia. Am. Rev. Respir. Dis. 1977, 116, 589-615. [CrossRef] [PubMed]

17. Matthay, M.A.; Zemans, R.L. The acute respiratory distress syndrome: Pathogenesis and treatment. Annu. Rev. Pathol. 2011, 6, 147-163. [CrossRef] [PubMed]

18. Huppert, L.A.; Matthay, M.A.; Ware, L.B. Pathogenesis of Acute Respiratory Distress Syndrome. Semin. Respir. Crit. Care Med. 2019, 40, 31-39. [CrossRef]

19. Kim, T.H.; Hong, S.B.; Lim, C.M.; Koh, Y.; Jang, E.Y.; Huh, J.W. The Role of Exosomes in Bronchoalveloar Lavage from Patients with Acute Respiratory Distress Syndrome. J. Clin. Med. 2019, 8, 1148. [CrossRef]

20. Pugin, J.; Verghese, G.; Widmer, M.C.; Matthay, M.A. The alveolar space is the site of intense inflammatory and profibrotic reactions in the early phase of acute respiratory distress syndrome. Crit. Care Med. 1999, 27, 304-312. [CrossRef]

21. Yang, C.Y.; Chen, C.S.; Yiang, G.T.; Cheng, Y.L.; Yong, S.B.; Wu, M.Y.; Li, C.J. New Insights into the Immune Molecular Regulation of the Pathogenesis of Acute Respiratory Distress Syndrome. Int. J. Mol. Sci. 2018, 19, 588. [CrossRef] [PubMed]

22. Ware, L.B.; Herridge, M. Acute lung injury. Semin. Respir. Crit. Care Med. 2013, 34, 439-440. [CrossRef]

23. Weiss, S.J. Tissue destruction by neutrophils. N. Engl. J. Med. 1989, 320, 365-376. [PubMed]

24. Babior, B.M.; Takeuchi, C.; Ruedi, J.; Gutierrez, A.; Wentworth, P., Jr. Investigating antibody-catalyzed ozone generation by human neutrophils. Proc. Natl. Acad. Sci. USA 2003, 100, 3031-3034. [CrossRef] [PubMed]

25. Stormann, P.; Becker, N.; Vollrath, J.T.; Kohler, K.; Janicova, A.; Wutzler, S.; Hildebrand, F.; Marzi, I.; Relja, B. Early Local Inhibition of Club Cell Protein 16 Following Chest Trauma Reduces Late Sepsis-Induced Acute Lung Injury. J. Clin. Med. 2019, 8, 896. [CrossRef] [PubMed]

26. Chang, J.C. Acute Respiratory Distress Syndrome as an Organ Phenotype of Vascular Microthrombotic Disease: Based on Hemostatic Theory and Endothelial Molecular Pathogenesis. Clin. Appl. Thromb. Hemost. 2019, 25, 1076029619887437. [CrossRef] [PubMed]

27. Matthay, M.A.; Wiener-Kronish, J.P. Intact epithelial barrier function is critical for the resolution of alveolar edema in humans. Am. Rev. Respir. Dis. 1990, 142, 1250-1257. [CrossRef]

28. Perkins, G.D.; Nathani, N.; McAuley, D.F.; Gao, F.; Thickett, D.R. In vitro and in vivo effects of salbutamol on neutrophil function in acute lung injury. Thorax 2007, 62, 36-42. [CrossRef]

29. Abraham, E. Neutrophils and acute lung injury. Crit. Care Med. 2003, 31, S195-S199. [CrossRef]

30. Frank, J.A.; Wray, C.M.; McAuley, D.F.; Schwendener, R.; Matthay, M.A. Alveolar macrophages contribute to alveolar barrier dysfunction in ventilator-induced lung injury. Am. J. Physiol. Lung Cell. Mol. Physiol. 2006, 291, L1191-L1198. [CrossRef]

31. Matthay, M.A.; Zimmerman, G.A.; Esmon, C.; Bhattacharya, J.; Coller, B.; Doerschuk, C.M.; Floros, J.; Gimbrone, M.A., Jr.; Hoffman, E.; Hubmayr, R.D.; et al. Future research directions in acute lung injury: Summary of a National Heart, Lung, and Blood Institute working group. Am. J. Respir. Crit. Care Med. 2003, 167, 1027-1035. [CrossRef] [PubMed]

32. Matthay, M.A.; Zimmerman, G.A. Acute lung injury and the acute respiratory distress syndrome: Four decades of inquiry into pathogenesis and rational management. Am. J.Respir. Cell Mol. Biol. 2005, 33, 319-327. [CrossRef] [PubMed]

33. Gadek, J.E. Adverse effects of neutrophils on the lung. Am. J. Med. 1992, 92, 27S-31S. [CrossRef]

34. Grimminger, F.; Menger, M.; Becker, G.; Seeger, W. Potentiation of leukotriene production following sequestration of neutrophils in isolated lungs: Indirect evidence for intercellular leukotriene A4 transfer. Blood 1988, 72, 1687-1692. [CrossRef]

35. Fantone, J.C.; Ward, P.A. Role of oxygen-derived free radicals and metabolites in leukocyte-dependent inflammatory reactions. Am. J. Pathol. 1982, 107, 395-418.

36. Matthay, M.A.; Ware, L.B.; Zimmerman, G.A. The acute respiratory distress syndrome. J. Clin. Investig. 2012, 122, 2731-2740. [CrossRef]

37. Zarbock, A.; Polanowska-Grabowska, R.K.; Ley, K. Platelet-neutrophil-interactions: Linking hemostasis and inflammation. Blood Rev. 2007, 21, 99-111. [CrossRef] 
38. Privratsky, J.R.; Paddock, C.M.; Florey, O.; Newman, D.K.; Muller, W.A.; Newman, P.J. Relative contribution of PECAM-1 adhesion and signaling to the maintenance of vascular integrity. J. Cell Sci. 2011, 124, 1477-1485. [CrossRef] [PubMed]

39. Villar, J.; Zhang, H.; Slutsky, A.S. Lung Repair and Regeneration in ARDS: Role of PECAM1 and Wnt Signaling. Chest 2019, 155, 587-594. [CrossRef]

40. Zarbock, A.; Singbartl, K.; Ley, K. Complete reversal of acid-induced acute lung injury by blocking of platelet-neutrophil aggregation. J. Clin. Investig. 2006, 116, 3211-3219. [CrossRef]

41. Kiefmann, R.; Heckel, K.; Schenkat, S.; Dorger, M.; Wesierska-Gadek, J.; Goetz, A.E. Platelet-endothelial cell interaction in pulmonary micro-circulation: The role of PARS. Thromb. Haemost. 2004, 91, 761-770. [CrossRef]

42. Kiefmann, R.; Heckel, K.; Schenkat, S.; Dorger, M.; Goetz, A.E. Role of p-selectin in platelet sequestration in pulmonary capillaries during endotoxemia. J. Vasc. Res. 2006, 43, 473-481. [CrossRef]

43. Wang, Y.; Zhong, M.; Wang, Z.; Song, J.; Wu, W.; Zhu, D. The preventive effect of antiplatelet therapy in acute respiratory distress syndrome: A meta-analysis. Crit. Care 2018, 22, 60. [CrossRef]

44. Panka, B.A.; de Grooth, H.J.; Spoelstra-de Man, A.M.; Looney, M.R.; Tuinman, P.R. Prevention or Treatment of Ards With Aspirin: A Review of Preclinical Models and Meta-Analysis of Clinical Studies. Shock 2017, 47, 13-21. [CrossRef] [PubMed]

45. Hamid, U.; Krasnodembskaya, A.; Fitzgerald, M.; Shyamsundar, M.; Kissenpfennig, A.; Scott, C.; Lefrancais, E.; Looney, M.R.; Verghis, R.; Scott, J.; et al. Aspirin reduces lipopolysaccharide-induced pulmonary inflammation in human models of ARDS. Thorax 2017, 72, 971-980. [CrossRef] [PubMed]

46. Frantzeskaki, F.; Armaganidis, A.; Orfanos, S.E. Immunothrombosis in Acute Respiratory Distress Syndrome: Cross Talks between Inflammation and Coagulation. Respiration 2017, 93, 212-225. [CrossRef] [PubMed]

47. Zarbock, A.; Ley, K. The role of platelets in acute lung injury (ALI). Front. Biosci. 2009, 14, 150-158. [CrossRef] [PubMed]

48. Ruggeri, Z.M. Von Willebrand factor. Curr. Opin. Hematol. 2003, 10, 142-149. [CrossRef] [PubMed]

49. Ruggeri, Z.M.; Dent, J.A.; Saldivar, E. Contribution of distinct adhesive interactions to platelet aggregation in flowing blood. Blood 1999, 94, 172-178. [CrossRef]

50. Jurk, K.; Clemetson, K.J.; de Groot, P.G.; Brodde, M.F.; Steiner, M.; Savion, N.; Varon, D.; Sixma, J.J.; Van Aken, H.; Kehrel, B.E. Thrombospondin-1 mediates platelet adhesion at high shear via glycoprotein Ib (GPIb): An alternative/backup mechanism to von Willebrand factor. FASEB J. 2003, 17, 1490-1492. [CrossRef]

51. Savage, B.; Almus-Jacobs, F.; Ruggeri, Z.M. Specific synergy of multiple substrate-receptor interactions in platelet thrombus formation under flow. Cell 1998, 94, 657-666. [CrossRef]

52. Kasirer-Friede, A.; Kahn, M.L.; Shattil, S.J. Platelet integrins and immunoreceptors. Immunol. Rev. 2007, 218, 247-264. [CrossRef]

53. Washington, A.V.; Esponda, O.; Gibson, A. Platelet biology of the rapidly failing lung. Br. J. Haematol. 2020, 188, 641-651. [CrossRef] [PubMed]

54. Lax, S.; Rayes, J.; Wichaiyo, S.; Haining, E.J.; Lowe, K.; Grygielska, B.; Laloo, R.; Flodby, P.; Borok, Z.; Crandall, E.D.; et al. Platelet CLEC-2 protects against lung injury via effects of its ligand podoplanin on inflammatory alveolar macrophages in the mouse. Am. J. Physiol. Lung Cell. Mol. Physiol. 2017, 313, L1016-L1029. [CrossRef] [PubMed]

55. Nieswandt, B.; Echtenacher, B.; Wachs, F.P.; Schroder, J.; Gessner, J.E.; Schmidt, R.E.; Grau, G.E.; Mannel, D.N. Acute systemic reaction and lung alterations induced by an antiplatelet integrin gpIIb/IIIa antibody in mice. Blood 1999, 94, 684-693. [CrossRef]

56. Koedam, J.A.; Cramer, E.M.; Briend, E.; Furie, B.; Furie, B.C.; Wagner, D.D. P-selectin, a granule membrane protein of platelets and endothelial cells, follows the regulated secretory pathway in AtT-20 cells. J. Cell Biol. 1992, 116, 617-625. [CrossRef]

57. Tabuchi, A.; Kuebler, W.M. Endothelium-platelet interactions in inflammatory lung disease. Vasc. Pharmacol. 2008, 49, 141-150. [CrossRef]

58. Urzainqui, A.; Serrador, J.M.; Viedma, F.; Yanez-Mo, M.; Rodriguez, A.; Corbi, A.L.; Alonso-Lebrero, J.L.; Luque, A.; Deckert, M.; Vazquez, J.; et al. ITAM-based interaction of ERM proteins with Syk mediates signaling by the leukocyte adhesion receptor PSGL-1. Immunity 2002, 17, 401-412. [CrossRef] 
59. Haselmayer, P.; Grosse-Hovest, L.; von Landenberg, P.; Schild, H.; Radsak, M.P. TREM-1 ligand expression on platelets enhances neutrophil activation. Blood 2007, 110, 1029-1035. [CrossRef]

60. Zhao, C.; Su, E.M.; Yang, X.; Gao, Z.; Li, L.; Wu, H.; Jiang, Y.; Su, X. Important role of platelets in modulating endotoxin-induced lung inflammation in CFTR-deficient mice. PLoS ONE 2013, 8, e82683. [CrossRef]

61. Morales-Ortiz, J.; Deal, V.; Reyes, F.; Maldonado-Martinez, G.; Ledesma, N.; Staback, F.; Croft, C.; Pacheco, A.; Ortiz-Zuazaga, H.; Yost, C.C.; et al. Platelet-derived TLT-1 is a prognostic indicator in ALI/ARDS and prevents tissue damage in the lungs in a mouse model. Blood 2018, 132, 2495-2505. [CrossRef] [PubMed]

62. Caudrillier, A.; Kessenbrock, K.; Gilliss, B.M.; Nguyen, J.X.; Marques, M.B.; Monestier, M.; Toy, P.; Werb, Z.; Looney, M.R. Platelets induce neutrophil extracellular traps in transfusion-related acute lung injury. J. Clin. Investig. 2012, 122, 2661-2671. [CrossRef] [PubMed]

63. Vieira-de-Abreu, A.; Campbell, R.A.; Weyrich, A.S.; Zimmerman, G.A. Platelets: Versatile effector cells in hemostasis, inflammation, and the immune continuum. Semin. Immunopathol. 2012, 34, 5-30. [CrossRef] [PubMed]

64. Cerletti, C.; Tamburrelli, C.; Izzi, B.; Gianfagna, F.; de Gaetano, G. Platelet-leukocyte interactions in thrombosis. Thromb. Res. 2012, 129, 263-266. [CrossRef] [PubMed]

65. Zarbock, A.; Bishop, J.; Muller, H.; Schmolke, M.; Buschmann, K.; Van Aken, H.; Singbartl, K. Chemokine homeostasis vs. chemokine presentation during severe acute lung injury: The other side of the Duffy antigen receptor for chemokines. Am. J. Physiol. Lung Cell. Mol. Physiol. 2010, 298, L462-L471. [CrossRef]

66. Ortiz-Munoz, G.; Mallavia, B.; Bins, A.; Headley, M.; Krummel, M.F.; Looney, M.R. Aspirin-triggered 15-epi-lipoxin A4 regulates neutrophil-platelet aggregation and attenuates acute lung injury in mice. Blood 2014, 124, 2625-2634. [CrossRef]

67. Goldman, G.; Welbourn, R.; Kobzik, L.; Valeri, C.R.; Shepro, D.; Hechtman, H.B. Synergism between leukotriene B4 and thromboxane A2 in mediating acid-aspiration injury. Surgery 1992, 111, 55-61.

68. Wahn, H.; Hammerschmidt, S. Influence of cyclooxygenase and lipoxygenase inhibitors on oxidative stress-induced lung injury. Crit. Care Med. 2001, 29, 802-807. [CrossRef]

69. Looney, M.R.; Nguyen, J.X.; Hu, Y.; Van Ziffle, J.A.; Lowell, C.A.; Matthay, M.A. Platelet depletion and aspirin treatment protect mice in a two-event model of transfusion-related acute lung injury. J. Clin. Investig. 2009, 119, 3450-3461. [CrossRef]

70. Nagase, T.; Uozumi, N.; Ishii, S.; Kume, K.; Izumi, T.; Ouchi, Y.; Shimizu, T. Acute lung injury by sepsis and acid aspiration: A key role for cytosolic phospholipase A2. Nat. Immunol. 2000, 1, 42-46. [CrossRef]

71. Kostopanagiotou, G.; Avgerinos, E.; Costopanagiotou, C.; Arkadopoulos, N.; Andreadou, I.; Diamantopoulou, K.; Lekka, M.; Smyrniotis, V.; Nakos, G. Acute lung injury in a rat model of intestinal ischemia-reperfusion: The potential time depended role of phospholipases A(2). J. Surg. Res. 2008, 147, 108-116. [CrossRef] [PubMed]

72. Pittet, J.F.; Mackersie, R.C.; Martin, T.R.; Matthay, M.A. Biological markers of acute lung injury: Prognostic and pathogenetic significance. Am. J. Respir. Crit. Care Med. 1997, 155, 1187-1205. [CrossRef]

73. Lv, W.; Wang, S.; Wang, L.; Wu, Z.; Jiang, Y.; Chen, X.; Gao, R. G994T polymorphism in exon 9 of plasma platelet-activating factor acetylhydrolase gene and lung ultrasound score as prognostic markers in evaluating the outcome of acute respiratory distress syndrome. Exp. Ther. Med. 2019, 17, 3174-3180. [CrossRef] [PubMed]

74. Hudson, L.D.; Milberg, J.A.; Anardi, D.; Maunder, R.J. Clinical risks for development of the acute respiratory distress syndrome. Am. J. Respir. Crit. Care Med. 1995, 151, 293-301. [CrossRef] [PubMed]

75. Donnelly, S.C.; Haslett, C. Cellular mechanisms of acute lung injury: Implications for future treatment in the adult respiratory distress syndrome. Thorax 1992, 47, 260-263. [CrossRef]

76. Semple, J.W.; Italiano, J.E., Jr.; Freedman, J. Platelets and the immune continuum. Nat. Rev. Immunol. 2011, 11, 264-274. [CrossRef]

77. Brinkmann, V.; Zychlinsky, A. Beneficial suicide: Why neutrophils die to make NETs. Nat. Rev. Microbiol. 2007, 5, 577-582. [CrossRef]

78. Gupta, A.K.; Hasler, P.; Holzgreve, W.; Gebhardt, S.; Hahn, S. Induction of neutrophil extracellular DNA lattices by placental microparticles and IL-8 and their presence in preeclampsia. Hum. Immunol. 2005, 66, 1146-1154. [CrossRef] 
79. Kessenbrock, K.; Krumbholz, M.; Schonermarck, U.; Back, W.; Gross, W.L.; Werb, Z.; Grone, H.J.; Brinkmann, V.; Jenne, D.E. Netting neutrophils in autoimmune small-vessel vasculitis. Nat. Med. 2009, 15, 623-625. [CrossRef]

80. Lande, R.; Ganguly, D.; Facchinetti, V.; Frasca, L.; Conrad, C.; Gregorio, J.; Meller, S.; Chamilos, G.; Sebasigari, R.; Riccieri, V.; et al. Neutrophils activate plasmacytoid dendritic cells by releasing self-DNA-peptide complexes in systemic lupus erythematosus. Sci. Transl. Med. 2011, 3, 73ra19. [CrossRef]

81. Chang, Y.W.; Tseng, C.P.; Lee, C.H.; Hwang, T.L.; Chen, Y.L.; Su, M.T.; Chong, K.Y.; Lan, Y.W.; Wu, C.C.; Chen, K.J.; et al. beta-Nitrostyrene derivatives attenuate LPS-mediated acute lung injury via the inhibition of neutrophil-platelet interactions and NET release. Am. J. Physiol. Lung Cell. Mol. Physiol. 2018, 314, L654-L669. [CrossRef] [PubMed]

82. Chen, Z.T.; Li, S.L.; Cai, E.Q.; Wu, W.L.; Jin, J.S.; Zhu, B. LPS induces pulmonary intravascular macrophages producing inflammatory mediators via activating NF-kappaB. J. Cell. Biochem. 2003, 89, 1206-1214. [CrossRef] [PubMed]

83. Tuinman, P.R.; Muller, M.C.; Jongsma, G.; Hegeman, M.A.; Juffermans, N.P. High-dose acetylsalicylic acid is superior to low-dose as well as to clopidogrel in preventing lipopolysaccharide-induced lung injury in mice. Shock 2013, 40, 334-338. [CrossRef]

84. Kario, K.; Eguchi, K.; Hoshide, S.; Hoshide, Y.; Umeda, Y.; Mitsuhashi, T.; Shimada, K. U-curve relationship between orthostatic blood pressure change and silent cerebrovascular disease in elderly hypertensives: Orthostatic hypertension as a new cardiovascular risk factor. J. Am. Coll. Cardiol. 2002, 40, 133-141. [CrossRef]

85. Eickmeier, O.; Seki, H.; Haworth, O.; Hilberath, J.N.; Gao, F.; Uddin, M.; Croze, R.H.; Carlo, T.; Pfeffer, M.A.; Levy, B.D. Aspirin-triggered resolvin D1 reduces mucosal inflammation and promotes resolution in a murine model of acute lung injury. Mucosal Immunol. 2013, 6, 256-266. [CrossRef]

86. Bates, J.J.; Watson, R.W.; Glynn, C.M.; O’Neill, A.J.; Fitzpatrick, J.M.; Buggy, D.J. Aspirin preserves neutrophil apoptosis after cardiopulmonary bypass. Shock 2004, 21, 495-499. [CrossRef] [PubMed]

87. Claria, J.; Serhan, C.N. Aspirin triggers previously undescribed bioactive eicosanoids by human endothelial cell-leukocyte interactions. Proc. Natl. Acad. Sci. USA 1995, 92, 9475-9479. [CrossRef] [PubMed]

88. Serhan, C.N. Lipoxins and aspirin-triggered 15-epi-lipoxins are the first lipid mediators of endogenous anti-inflammation and resolution. Prostaglandins Leukot. Essent. Fat. Acids 2005, 73, 141-162. [CrossRef] [PubMed]

89. Levy, B.D.; Clish, C.B.; Schmidt, B.; Gronert, K.; Serhan, C.N. Lipid mediator class switching during acute inflammation: Signals in resolution. Nat. Immunol. 2001, 2, 612-619. [CrossRef] [PubMed]

90. Serhan, C.N. Resolution phase of inflammation: Novel endogenous anti-inflammatory and proresolving lipid mediators and pathways. Annu. Rev. Immunol. 2007, 25, 101-137. [CrossRef] [PubMed]

91. Matute-Bello, G.; Liles, W.C.; Radella, F., 2nd; Steinberg, K.P.; Ruzinski, J.T.; Jonas, M.; Chi, E.Y.; Hudson, L.D.; Martin, T.R. Neutrophil apoptosis in the acute respiratory distress syndrome. Am. J. Respir. Crit. Care Med. 1997, 156, 1969-1977. [CrossRef] [PubMed]

92. El Kebir, D.; Jozsef, L.; Pan, W.; Wang, L.; Petasis, N.A.; Serhan, C.N.; Filep, J.G. 15-epi-lipoxin A4 inhibits myeloperoxidase signaling and enhances resolution of acute lung injury. Am. J. Respir. Crit. Care Med. 2009, 180, 311-319. [CrossRef] [PubMed]

93. Sun, Y.P.; Oh, S.F.; Uddin, J.; Yang, R.; Gotlinger, K.; Campbell, E.; Colgan, S.P.; Petasis, N.A.; Serhan, C.N. Resolvin D1 and its aspirin-triggered 17R epimer. Stereochemical assignments, anti-inflammatory properties, and enzymatic inactivation. J. Biol. Chem. 2007, 282, 9323-9334. [CrossRef]

94. Tang, H.; Liu, Y.; Yan, C.; Petasis, N.A.; Serhan, C.N.; Gao, H. Protective actions of aspirin-triggered (17R) resolvin D1 and its analogue, 17R-hydroxy-19-para-fluorophenoxy-resolvin D1 methyl ester, in C5a-dependent IgG immune complex-induced inflammation and lung injury. J. Immunol. 2014, 193, 3769-3778. [CrossRef] [PubMed]

95. Chen, C.M.; Tung, Y.T.; Wei, C.H.; Lee, P.Y.; Chen, W. Anti-Inflammatory and Reactive Oxygen Species Suppression through Aspirin Pretreatment to Treat Hyperoxia-Induced Acute Lung Injury in NF-kappaB-Luciferase Inducible Transgenic Mice. Antioxidants 2020, 9, 429. [CrossRef]

96. Cox, R., Jr.; Phillips, O.; Fukumoto, J.; Fukumoto, I.; Tamarapu Parthasarathy, P.; Arias, S.; Cho, Y.; Lockey, R.F.; Kolliputi, N. Aspirin-Triggered Resolvin D1 Treatment Enhances Resolution of Hyperoxic Acute Lung Injury. Am. J. Respir. Cell Mol. Biol. 2015, 53, 422-435. [CrossRef] [PubMed] 
97. Schmitt-Sody, M.; Metz, P.; Gottschalk, O.; Zysk, S.; Birkenmaier, C.; Goebl, M.; von Schulze Pellengahr, C.; Veihelmann, A.; Jansson, V. Selective inhibition of platelets by the GPIIb/IIIa receptor antagonist Tirofiban reduces leukocyte-endothelial cell interaction in murine antigen-induced arthritis. Inflamm. Res. 2007, 56, 414-420. [CrossRef]

98. Le, V.B.; Schneider, J.G.; Boergeling, Y.; Berri, F.; Ducatez, M.; Guerin, J.L.; Adrian, I.; Errazuriz-Cerda, E.; Frasquilho, S.; Antunes, L.; et al. Platelet activation and aggregation promote lung inflammation and influenza virus pathogenesis. Am. J. Respir. Crit. Care Med. 2015, 191, 804-819. [CrossRef]

99. Sharron, M.; Hoptay, C.E.; Wiles, A.A.; Garvin, L.M.; Geha, M.; Benton, A.S.; Nagaraju, K.; Freishtat, R.J. Platelets induce apoptosis during sepsis in a contact-dependent manner that is inhibited by GPIIb/IIIa blockade. PLoS ONE 2012, 7, e41549. [CrossRef]

100. Dorsam, R.T.; Kunapuli, S.P. Central role of the P2Y12 receptor in platelet activation. J. Clin. Investig. 2004, 113, 340-345. [CrossRef]

101. Muhlestein, J.B. Effect of antiplatelet therapy on inflammatory markers in atherothrombotic patients. Thromb. Haemost. 2010, 103, 71-82. [CrossRef] [PubMed]

102. Harr, J.N.; Moore, E.E.; Wohlauer, M.V.; Fragoso, M.; Gamboni, F.; Liang, X.; Banerjee, A.; Silliman, C.C. Activated platelets in heparinized shed blood: The "second hit" of acute lung injury in trauma/hemorrhagic shock models. Shock 2011, 36, 595-603. [CrossRef] [PubMed]

103. Erlich, J.M.; Talmor, D.S.; Cartin-Ceba, R.; Gajic, O.; Kor, D.J. Prehospitalization antiplatelet therapy is associated with a reduced incidence of acute lung injury: A population-based cohort study. Chest 2011, 139, 289-295. [CrossRef] [PubMed]

104. O’Neal, H.R., Jr.; Koyama, T.; Koehler, E.A.; Siew, E.; Curtis, B.R.; Fremont, R.D.; May, A.K.; Bernard, G.R.; Ware, L.B. Prehospital statin and aspirin use and the prevalence of severe sepsis and acute lung injury/acute respiratory distress syndrome. Crit. Care Med. 2011, 39, 1343-1350. [CrossRef]

105. Kor, D.J.; Erlich, J.; Gong, M.N.; Malinchoc, M.; Carter, R.E.; Gajic, O.; Talmor, D.S.; Illness, U.S.C.; Injury Trials Group: Lung Injury Prevention Study Investigators. Association of prehospitalization aspirin therapy and acute lung injury: Results of a multicenter international observational study of at-risk patients. Crit. Care Med. 2011, 39, 2393-2400. [CrossRef]

106. Chen, W.; Janz, D.R.; Bastarache, J.A.; May, A.K.; O’Neal, H.R., Jr.; Bernard, G.R.; Ware, L.B. Prehospital aspirin use is associated with reduced risk of acute respiratory distress syndrome in critically ill patients: A propensity-adjusted analysis. Crit. Care Med. 2015, 43, 801-807. [CrossRef]

107. Boyle, A.J.; Di Gangi, S.; Hamid, U.I.; Mottram, L.J.; McNamee, L.; White, G.; Cross, L.J.; McNamee, J.J.; O'Kane, C.M.; McAuley, D.F. Aspirin therapy in patients with acute respiratory distress syndrome (ARDS) is associated with reduced intensive care unit mortality: A prospective analysis. Crit. Care 2015, 19, 109. [CrossRef] [PubMed]

108. Kor, D.J.; Talmor, D.S.; Banner-Goodspeed, V.M.; Carter, R.E.; Hinds, R.; Park, P.K.; Gajic, O.; Gong, M.N.; Illness, U.S.C.; Injury Trials Group: Lung Injury Prevention with Aspirin Study Group. Lung Injury Prevention with Aspirin (LIPS-A): A protocol for a multicentre randomised clinical trial in medical patients at high risk of acute lung injury. BMJ Open 2012, 2. [CrossRef] [PubMed]

109. Kor, D.J.; Carter, R.E.; Park, P.K.; Festic, E.; Banner-Goodspeed, V.M.; Hinds, R.; Talmor, D.; Gajic, O.; Ware, L.B.; Gong, M.N.; et al. Effect of Aspirin on Development of ARDS in At-Risk Patients Presenting to the Emergency Department: The LIPS-A Randomized Clinical Trial. JAMA 2016, 315, 2406-2414. [CrossRef] [PubMed]

110. Toner, P.; McAuley, D.F.; Shyamsundar, M. Aspirin as a potential treatment in sepsis or acute respiratory distress syndrome. Crit. Care 2015, 19, 374. [CrossRef]

111. Yu, H.; Ni, Y.N.; Liang, Z.A.; Liang, B.M.; Wang, Y. The effect of aspirin in preventing the acute respiratory distress syndrome/acute lung injury: A meta-analysis. Am. J. Emerg. Med. 2018, 36, 1486-1491. [CrossRef]

112. Jin, W.; Chuang, C.C.; Jin, H.; Ye, J.; Kandaswamy, E.; Wang, L.; Zuo, L. Effects of Pre-Hospital Antiplatelet Therapy on the Incidence of ARDS. Respir. Care 2020, 65, 1039-1045. [CrossRef] [PubMed]

113. Mohananey, D.; Sethi, J.; Villablanca, P.A.; Ali, M.S.; Kumar, R.; Baruah, A.; Bhatia, N.; Agrawal, S.; Hussain, Z.; Shamoun, F.E.; et al. Effect of antiplatelet therapy on mortality and acute lung injury in critically ill patients: A systematic review and meta-analysis. Ann. Card. Anaesth. 2016, 19, 626-637. [PubMed] 
114. Sinha, P.; Churpek, M.M.; Calfee, C.S. Machine Learning Classifier Models Can Identify ARDS Phenotypes Using Readily Available Clinical Data. Am. J. Respir. Crit. Care Med. 2020, 201, A1014. [CrossRef]

115. Sinha, P.; Delucchi, K.L.; McAuley, D.F.; O'Kane, C.M.; Matthay, M.A.; Calfee, C.S. Development and validation of parsimonious algorithms to classify acute respiratory distress syndrome phenotypes: A secondary analysis of randomised controlled trials. Lancet Respir. Med. 2020, 8, 247-257. [CrossRef]

(C) 2020 by the authors. Licensee MDPI, Basel, Switzerland. This article is an open access article distributed under the terms and conditions of the Creative Commons Attribution (CC BY) license (http://creativecommons.org/licenses/by/4.0/). 